\title{
Pemanfaatan Vegetasi Mangrove sebagai Obat-obatan Tradisional pada Lima Suku di Papua
}

\author{
Utilization of Mangrove Vegetation as Tradisional Medicines for Five Ethnics Groups in \\ Papua
}

\author{
Mahmud dan Wahyudi* \\ Fakultas Kehutanan, Universitas Papua, Manokwari- Papua Barat 98314 \\ Email: wahyudi.s.pono@gmail.com *Penulis untuk korespondensi
}

\begin{abstract}
Mangrove plays important role to coastal communities across Papua. Mangrove provides food, material construction, firewood, medicine, shelter and others. This research is designed to determine the traditional practices of utilizing mangrove vegetation used for medicinal material remedieson for five ethnicgroups in Papua. Field observation, and intensive literature reviews were used to collect the data and information required. The results showed that seven spesies of mangrove belonging to five families were used for medicinal puposes by five ethnic groups in Papua. Utilizations of mangrove as traditional medicines could be used for treatments for twelve diseases or health syndromes, ranging from mosquito repellency, scabies medicine, cleanse for pregnancey, children's speaking ability, insecticides, malaria medicine, tooth medicine, diarrhoea, energy booster and stimulant for birth delivery. More importanly, the method of extraction, preparation and dosages of comsumption among five ethnics groups are almost similar.
\end{abstract}

Keywords: Mangrove vegetation, traditional medicines, five ethnics, Papua

\begin{abstract}
Abstrak
Vegetasi mangrove berperan penting dan cukup nyata, serta merupakan salah satu bagian penting dalam kehidupan masyarakat Papua, khususnya yang berdomisili di pesisir pantai. Mangrove dimanfaatkan sebagai sumber makanan, kayu bakar, obat-obatan tradisional, dan pelindung dari bahaya tsunami, badai, dan aberasi air laut. Penelitian ini dilakukan menggunakan metode observasi lapangan dan studi pustaka. Tujuan penelitian ini mengetahui pemanfaatan vegetasi mangrove sebagai tumbuhan berkhasiat obat pada lima suku pesisir di tanah Papua. Hasil penelitian menunjukkan bahwa sebanyak tujuh jenis dari lima famili vegetasi mangrove yang dimanfaatkan sebagai tumbuhan berkhasiat obat, untuk mengobati dua belas penyakit atau gejala penyakit, termasuk pestisida alami.
\end{abstract}

Kata kunci: Vegetasi mangrove, obat tradisional, lima suku, Papua

Diterima: 10 Oktober 2013, disetujui: 13 Desember 2013

\section{Pendahuluan}

Kualitas dan kuantitas keanekaragaman hayati mulai menurun, jenis-jenis flora dan fauna yang belum diketahui potensi, jenis, jumlah, dan pemanfaatanya menjadi hilang sebagai akibat konversi hutan dan pembukaan hutan untuk lahan pertanian, pemukiman, dan perkebunan yang semakin meningkat (Mahmud, 2011). Hal ini membutuhkan perhatian serius dari semua pihak, karena bila kerusakan hutan tidak dicegah akan membawa dampak hilangnya jenis-jenis endemik yang belum terdata dan terdokumentasi pada daerah tersebut, termasuk di dalamnya adalah prektek-praktek pengetahuan lokal (indigenous knowledge).

Laksono dkk., (2000) mengemukakan bahwa masyarakat suku-suku yang tinggal di daerah terpencil dan di sekitar pesisir memiliki keunikan tersendiri dalam memanfaatkan mangrove. Secara tradisional semua bagianbagian mangrove seperti batang, daun, tangkai, akar, buah dan bijinya dapat dimanfaatkan oleh manusia untuk berbagai keperluan (Santoso 
dkk., 2005). Pemanfaatan vegetasi mangrove di Papua antar suku/daerah sangat berbeda-beda satu sama lainya baik spesies yang digunakan maupun cara meramu tumbuhan tersebut. Hal ini disebabkan perbedaan latar belakang, peralatan, sosiokultur dan perbedaan ekosistem lingkungan masing-masing daerah (Mahmud, 2011).

Pada suku Inanwatan di Sorong Selatan, vegetasi mangrove dimanfaatkan sebagai bahan makanan, bahan energi, ritual, konstruksi bangunan, alat nelayan, alat bertani dan obatobatan (Bandi, 2006), sedangkan suku Senebuay juga memanfaatkan vegetasi mangrove sebagai bahan makanan, bahan energi, bahan peralatan dan kesenian (Leonard, 2003). Dari hasil penelitian pemanfaatan vegetasi mangrove yang dilakukan oleh Mahmud (2011) pada empat suku di Papua, dilaporkan bahwa terdapat tujuh jenis dari tiga famili mangrove yang dimanfaatkan sebagai bahan makanan. Ke-4 suku tersebut diantaranya suku Mandender di Biak, suku Sough di Bintuni, suku Ambay di Manokwari dan suku Inanwatan di Sorong Selatan.

Vegetasi mangrove selain bermanfaat sebagai bahan pangan dan kebutuhan lainnya bagi penduduk lokal, mangrove juga sebagai tanaman berkhasiat obat, sehingga dapat dimanfaatkan sebagai obat tradisional (traditional medicine) (Bandaranayake, 1998; Baba dkk., 2013). Pemanfaatan tumbuhan obat selama ini masih didominasi dari tumbuhan yang tumbuh di daratan dari pada perairan, misalnya beberapa suku di Papua suku Biak di kampung Swaipak memanfaatkan 23 jenis dari 19 famili (Rumadas, 2012), suku Meyah di kampung Saray memanfaatkan 23 jenis dari 17 famili di (Kasi, 2009).

Kecenderungan kebutuhan dan permintaan akan obat-obatan herbal semakin meningkat, seiring dengan kesadaran akan pentingnya bahan alam dan moto hidup kembali ke alam (back to nature). Menurut Wahyudi (2012) pengobatan dengan kombinasi beberapa bahan kimia yang terdapat dalam obat herbal terbukti lebih memberikan efek yang positif, dari pada menggunakan senyawa tunggal (single compound). Ke depan produk-produk herbal negara Indonesia akan mampu bersaing dengan produk-produk herbal dari negara China dan India, dua negara produsen obat herbal terkemuka saat ini.
Data terakhir dari Assosiasi Pengusaha Jamu Indonesia, menyatakan bahwa omset nilai penjualan produk jamu Indonesia cenderung terus meningkat, yaitu Rp. 8.5 trilyun pada tahun 2009 menjadi Rp. 11.5 trilyun pada tahun 2011, diperkirakan pada tahun 2015, akan mencapai omzet sekitar Rp. 20 trilyun. Di samping itu jamu Indonesia telah berhasil menembus pasar beberapa negara, seperti Hongkong, Taiwan, Amerika Serikat, Belanda, Suriname, Australia, China, India dan Afrika Selatan (Kompas, 2011). Informasi tentang potensi dan pemanfaatan vegetasi mangrove sebagai obat tradisional pada masyarakat tradisional di daerah pesisir tanah Papua masih minim, dan belum banyak diteliti. Obat tradisional memiliki potensi untuk dimanfaatkan sebagai usaha pencegahan atau pengobatan pendahuluan (first line treatment) beberapa menyakit endemik atau wabah, seperti malaria dan diare, sambil menunggu pengobatan modern (drug treatment), Wahyudi (2012). Padahal dewasa ini berbagai penyakit mewabah dan bahkan sulit untuk diobati. Kalaupun sembuh, maka dalam jangka waktu yang tidak lama, penyakit tersebut muncul kembali.

Penelitian ini bertujuan mengetahui pemanfaatan vegetasi mangrove sebagai obat tradisional pada lima suku yang ada di tanah Papua, dan diharapkan dapat menjadi bahan informasi, dan dokumentasi bagi masyarakat, peneliti, pemerintah, dan pihak-pihak berkepentingan dalam pengelolaan vegetasi mangrove.

\section{Metode Penelitian}

Penelitian ini dilaksanakan pada masyarakat suku Mandender di Biak, suku Sough di Bintuni, suku Inanwatan di Sorong Selatan, suku Mandori di Numfor, dan suku Ambay di Manokwari. Bahan dan peralatan yang diperlukan adalah alat tulis-menulis, kamera, alkohol/spiritus, kamera, roll meter, parang, gunting stek, quisioner, tally sheet dan buku identifikasi mangrove. Metode yang digunakan adalah deskriptif, dengan teknik wawancara semi-struktural. Telaah pustaka dilakukan untuk memperkaya informasi pemanfaatan vegetasi mangrove, sekaligus sebagai pembanding 
permanfaatan antara penduduk asli di tanah Papua.

Teknik penentuan responden contoh dilakukan secara purposif, yang dibagi menjadi tiga kategori responden, yaitu responden kunci, utama, dan responden umum. Responden kunci adalah Tabib (dukun), Peramu obat (tetua =bahasa lokal) yang sering mengobati orang jika ada pasien datang ke rumahnya. Responden utama terdiri dari kepala suku, tokoh masyarakat, kepala kampung dan tokoh agama. Sedangkan responden umum adalah anggota masyarakat lima suku tersebut yang mengetahui dan memanfaatkan vegetasi mangrove.

Variabel yang diamati adalah bentuk pemanfaatan, jenis, dan bagian tumbuhan yang dimanfaatkan. Pendekatan yang digunakan berdasarkan bentuk pemanfaatan sebagai bahan obat-obatan. Data yang diperoleh diolah secara tabulasi dan dianalisis secara deskriptif. Data disajikan dalam bentuk tabel dan gambar.

\section{Hasil dan Pembahasan}

\section{Jenis-jenis vegetasi mangrove}

Vegetasi mangrove tumbuh secara alami di sekitar pantai (pesisir) pada lima suku di Papua, yaitu suku Mandender di Biak, Sough di Bintuni, Inanwaran di Sorong Selatan, Mandori di Numfor, dan suku Ambay di Manokwari. Hasil penelitian menunjukkan bahwa ke-lima suku tersebut memanfaatkan vegetasi mangrove sebagai tanaman obat secara turun temurun. Tujuh jenis vegetasi mangrove dimanfaatkan oleh suku-suku asli tersebut, yang termasuk dalam lima famili. Vegetasi mangrove yang dimanfaatkan sebagai obat tradisional oleh lima suku asli di pesisir tanah berdasarkan jenis dan famili disajikan pada Gambar 1.

Gambar 1 menunjukkan bahwa tumbuhan obat dari vegetasi mangrove pada lima suku asli di pesisir tanah Papua, dari famili Rhizophoraceae dan Meliaceae masing-masing terdiri dari dua jenis secara berurutan yaitu Bruguiera gymnorrhiza Lam (Tumuk) dan Rhizopora apiculata Blume (Bakau), serta Xylocarpus granatum Koem dan Xylocarpus moluccensis. Sedangkan dari famili Sonneratiaceae, Combretaceae dan Sterculiaceae masing hanya terdiri dari satu jenis, yaitu
Sonneratia alba J.Sm, Lumnitzera littorea, dan Heritiera littoralis.

\section{Mangrove sebagai obat tradisional}

\section{Suku Mandender}

Mangrove yang terdapat di Teluk Duai telah dimanfaatkan oleh masyarakat suku Mandender sejak lama. Pengetahuan tersebut diperoleh dari percobaan bagian tumbuhan mangrove untuk mengobati penyakit tertentu. Apabila penyakitnya sembuh dan terdapat tandatanda sembuh maka pengetahuan tersebut menjadi pengalaman yang sangat berharga. Pengalaman dan kebiasaan seseorang yang kemudian diturunkan dari generasi berikutnya, sehingga pengetahuan yang berasal dari pengalaman dan kebiasaan tersebut hanya menjadi pengetahuan setempat (local indigenous knowledge), praktek-praktek tersebut dikenal dengan istilah kearifan lokal (Wahyudi, 2012). Pengetahuan tentang pemanfaatan mangrove baik untuk tumbuhan obat atau pemanfaatan lain berbeda-beda untuk setiap suku, dan perbedaan ini menunjukan kekhasan setiap suku dalam memanfaatkan mangrove (Abidondifu, 2007).

Tumbuhan obat penting untuk penyakit ringan sampai berat sebelum penderita dibawa ke rumah sakit atau dokter. Pemanfaatan vegetasi mangrove oleh masyarakat suku Mandender sebagai obat tradisional disajikan pada Tabel 1.

Tabel 1 menunjukan bahwa masyarakat suku Mandender memanfaatkan 3 jenis vegetasi mangrove sebagai obat tradisional yaitu jenis Bruguiera gymnorrhiza Lam, Sonneratia alba J.Sm dan Xylocarpus granatum Koen. Bagian tumbuhan yang dimanfaatkan sebagai obat antara lain adalah kulit batang, daun, dan buah. Sedangkan pemanfaatannya adalah dari obat kudis, perangsang balita untuk berbicara, pengusir nyamuk, dan pestisida alami. Masyarakat suku Mandender menggunakan mangrove sebagai obat tradisional karena sudah turun-temurun atau dari generasi ke generasi, mudah dijangkau/diperoleh, dan mereka meyakini bahwa obat tradisional tidak ada efek samping, oleh karenanya tetap dimanfaatkan sampai saat ini. Selain sebagai obat kudis (kulit), bunga dari Bruguiera gymnorrhiza Lam pada 
beberapa suku di Indonesia juga dimanfaatkan sebagai obat telinga (Purnobasuki, 2004).

\section{Suku Sough}

Vegetasi mangrove yang berada di Teluk Bintuni Papua Barat adalah salah satu habitat mangrove terbaik di dunia (Wahyudi dkk., 2013). Mangrove tersebut telah dimanfaatkan oleh masyarakat setempat secara turun temurun sebagai obat tradisional, namun hanya terbatas pada penyakit tertentu. Pemanfaatan vegetasi mangrove oleh masyarakat asli di Teluk Bintuni sebagai obat tradisional disajikan pada Tabel 2.

Tabel 2 memperlihatkan bahwa masyarakat suku Sough di Teluk Bintuni hanya memanfaatkan dua jenis vegetasi mangrove sebagai obat tradisional yaitu jenis Rhizopora apiculata dan Sonneratia alba J.Sm. Untuk jenis Rhizophora spp bagian tumbuhan yang dimanfaatkan adalah kulit untuk sakit gigi dan malaria, sedangkan akar muda diperuntukkan bagi penyakit mencret-mencret (diare). Kulit Sonneratia spp juga dimanfaatkan untuk obat sakit gigi. Suku Sough menggunakan mangrove sebagai obat tradisional karena sudah turuntemurun, dari generasi ke generasi, mudah dijangkau atau diperoleh, dan mereka meyakini obat tradisional tidak ada efek samping, sehingga digunakan sampai saat ini sebelum mereka pergi ke pusat layanan kesehatan terdekat. Rhizopora apiculata dan Sonneratia alba J. Sm di cagar alam Teluk Bintuni memiliki manfaat yang sama seperti Nypah fruticans, yaitu sebagai obat sakit gigi, pemanfaatannya adalah akarnya dibakar dan arangnya diletakkan pada gigi yang sakit (Sihite dkk., 2005). Selain sebagai obat gigi, malaria, dan mencret (diare) Rhizopora apiculata pada beberapa suku di Indonesia dimanfaatkan sebagai obat penyakit beri-beri, hepatitis haematoma, borok, bagian yang dimanfaatkan adalah kulit, batang, bunga, daun, dan akar (Purnobasuki, 2004).

\section{Suku Inanwatan}

Bagi suku Inanwatan di kampung Simbay Inanwatan Sorong Selatan, memanfaatkan obat tradisional tidak hanya dari hutan yang berada di daratan namun juga ada dari pesisir pantai atau vegetasi mangrove. Pemanfaatan vegetasi mangrove oleh masyarakat suku Inanwatan sebagai obat tradisional disajikan pada Tabel 3.

Dari Tabel 3, jenis vegetasi mangrove yang dimanfaatkan oleh masyarakat di kampung Simbay Inanwatan sebagai obat tradisional adalah Heritera littoralis, yaitu sebagai penambah stamina. Masyarakat telah lama mengkonsumsi sebagai obat kuat (energy), sehingga jarang mengkonsumsi suplemen atau minuman berenergi yang dijual di pasaran.

\section{Suku Ambay}

Suku Ambay adalah penduduk asli Papua, yang memanfaatkan vegetasi mangrove sebagai obat tradisional, yaitu Soneratia alba, Xylocarpus moluccensis dan Rhizopora apiculata. Penyakit, bagian tumbuhan yang dimanfaatkan, serta jenis vegetasi mangrove yang dipergunakan sebagai obat tradisional oleh suku Ambay, disajikan pada Tabel 4.

Tabel 4 menjelaskan bahwa tiga jenis vegetasi mangrove dimanfaatkan oleh masyarakat suku Ambay sebagai obat tradisional, untuk mengobati penyakit kudis, mempercepat melahirkan, dan menguatkan tulang, serta menghangatkan ibu hamil. Telah menjadi kebiasaan masyarakat suku Ambay agar balita mimiliki tulang kuat, karena itu mereka mengambil batang atau ranting dari Rhizopora apiculata. Batang tersebut dibakar menjadi arang, kemudian arang yang masih menyala diletakkan pada wajan atau belanga, kemudian jari-jari orang tua diletakkan diatas belanga atau wajan, setelah beberapa menit jari-jari terasa hangat, jari-jari tersebut mengurut secara pelanpelan ke bagian tubuh balita atau ibu hamil. Masyarakat sampai saat ini tetap memanfaatkan vegetasi mangrove sebagai obat tradisional karena sudah terbukti keampuhannya, mudah memperolehnya, tidak ada efek samping dan sudah turun-temurun dari nenek moyang mereka.

\section{Suku Mandori}

Menurut Krey (2012), masyarakat suku Mandori di Biak, memanfaatkan dua jenis tumbuhan mangrove sebagai obat tradisional yaitu Rhizopora apiculata dan Lumnitzera littorea, dan bagian yang dimanfaatkan terbatas hanya pada bunga dan kulit (Tabel 5).

Tabel 5 menjelaskan bahwa vegetasi mangrove dimanfaatkan oleh suku Mandori 
untuk mengobati penyakit diare, yaitu dari kulit Rhizophora spp, dan obat gatal dari bunga Lumnitceraspp. Pemanfaatan kulit Rhizophora spp untuk penyakit diare ini serupa dengan Suku Sough yang telah dilakukan pula sejak dahulu (Mahmud, 2011).

\section{Penyiapan ramuan obat tradisional}

Dalam menyiapkan ramuan obat tradisional, kelima suku asli di pesisir tanah Papua, pada umumnya memiliki kesamaan dalam meramu dan memakai ramuan tersebut (Tabel 6).

\section{Kandungan bahan aktif vegetasi mangrove}

Analisis fitokimia dari vegetasi mangrove jenis Avicennia marina, pada bagian daun, kulit batang, getah, akar, kulit buah, dan biji telah dilakukan oleh Wibowo dkk., 2009. Analisis kuantitif fitokimia pada daun, kulit batang, getah, dan akar ditemukan bahan aktif dari kelompok alkaloid, saponin, tanin, flavonoid, terpenoid, dan glikosida. Senyawa dari kelompok yang sama juga ditemukan pada bagian kulit buah dan biji. Kelompok fenolik hanya ditemukan pada bagian kulit buah dan biji.

Berbagai jenis kelas bahan aktif (metabolites) dari vegetasi seperti alkohol alifatik, asam amino, alkaloid, karbohidrat, karotenoid, hidrokarbon, asam lemak, asam lemak jenuh, lipida, feromones, senyawa fenol, steroid, triterpenes, dan glikosida, tannin telah berhasil diisolasi, dan dimanfaatkan untuk keperluan berbagai industri, termasuk pangan dan obat-obatan (Bandaranayake, 2002).

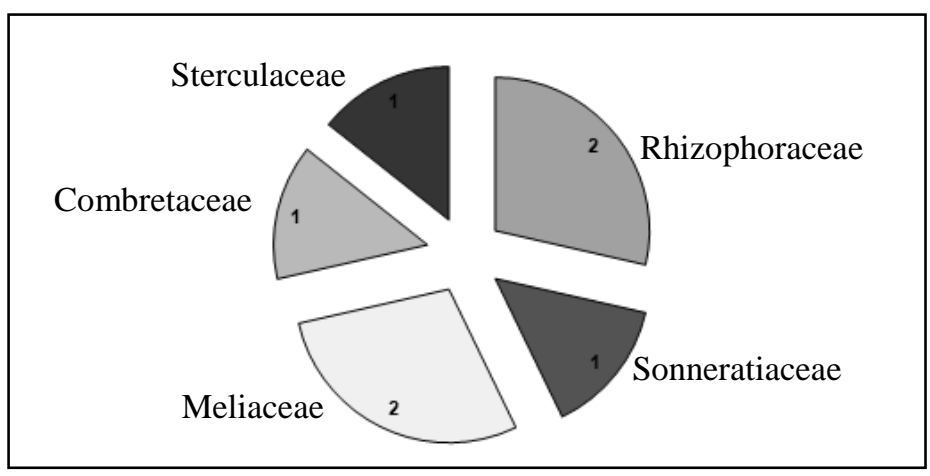

Gambar 1. Pemanfaatan vegetasi mangrove untuk obat tradisional oleh lima suku asli di pesisir tanah Papua berdasarkan jenis, dan familinya.

Tabel 1. Jenis mangrove yang dimanfaatkan sebagai obat tadisional oleh suku Mandender.

\begin{tabular}{|c|c|c|c|c|c|}
\hline No & $\begin{array}{l}\text { Nama } \\
\text { Lokal } \\
\end{array}$ & $\begin{array}{c}\text { Nama } \\
\text { Latin } \\
\end{array}$ & $\begin{array}{c}\text { Bagian yang } \\
\text { dimanfaatkan }\end{array}$ & Cara Pemanfaatan & Kegunaan \\
\hline 1. & Aibon & $\begin{array}{l}\text { Bruguiera } \\
\text { gymnorrhiza } \\
\text { Lam }\end{array}$ & & $\begin{array}{l}\text { Kulit batang diambil kemudian dicuci } \\
\text { dan direbus setelah itu airnya dipakai } \\
\text { untuk mandi }\end{array}$ & Sebagai obat kudis \\
\hline 2. & Swaikur & $\begin{array}{l}\text { Sonneratia } \\
\text { alba J.Sm }\end{array}$ & Kulit batang & $\begin{array}{l}\text { Kulit batang diambil kemudian dicuci } \\
\text { dan direbus. Air rebusan tadi dibiarkan } \\
\text { hingga hangat kemudian diminum. } \\
\text { Daun diambil kemudian didekatkan } \\
\text { pada mulutbayi dan dipatah-patahkan } \\
\text { beberapa kali (hal tersebut dapat } \\
\text { dilakukan beberapa kali). }\end{array}$ & $\begin{array}{l}\text { Untuk membersihkan } \\
\text { kandungan ibu setelah } \\
\text { melahirkan } \\
\text { Untuk merangsang } \\
\text { kecakapan dalam } \\
\text { berbicara khusus } \\
\text { untuk balita }\end{array}$ \\
\hline 3. & Kabau & $\begin{array}{l}\text { Xylocarpus } \\
\text { granatum } \\
\text { Koen }\end{array}$ & Buah & $\begin{array}{l}\text { Buah dibelah menjadi beberapa bagian } \\
\text { kemudian diletakkan pada sisi-sisi } \\
\text { kamar. } \\
\text { Buah dibelah menjadi beberapa bagian } \\
\text { kemudian diletakkan/dihambur pada } \\
\text { tempat bertani }\end{array}$ & $\begin{array}{l}\text { Sebagai obat pengusir } \\
\text { nyamuk } \\
\text { Sebagai pembasmi } \\
\text { serangga tanaman }\end{array}$ \\
\hline
\end{tabular}

Sumber: Abidondifu (2007) 
Tabel 2. Jenis mangrove yang dimanfaatkan sebagai obat tradisional di Teluk Bintuni Papua Barat.

\begin{tabular}{|c|c|c|c|c|c|}
\hline No. & $\begin{array}{l}\text { Nama } \\
\text { Lokal } \\
\end{array}$ & $\begin{array}{l}\text { Nama } \\
\text { Latin } \\
\end{array}$ & $\begin{array}{c}\text { Bagian yang } \\
\text { dimanfaatkan }\end{array}$ & Cara Pemanfaatan & Kegunaan \\
\hline \multirow[t]{2}{*}{1.} & \multirow[t]{2}{*}{ Parai } & \multirow[t]{2}{*}{$\begin{array}{l}\text { Rhizopora } \\
\text { apiculata }\end{array}$} & Akar muda & $\begin{array}{l}\text { Ambil akar muda, dibersihkan dan direbus } \\
\text { dengan air secukupnya sampai mendidih. } \\
\text { Kemudian dipakai untuk berkumur } \\
\text { Ambil akar muda, dibersihkan dan } \\
\text { dicampurkan dengan minuman lokal (Bobo) }\end{array}$ & $\begin{array}{l}\text { Sebagai obat sakit } \\
\text { gigi } \\
\text { Untuk obat sakit } \\
\text { malaria }\end{array}$ \\
\hline & & & Kulit & $\begin{array}{l}\text { Kulit batang dikupas dan kunyah seperti } \\
\text { mengunyah pinang }\end{array}$ & $\begin{array}{l}\text { Untuk obat } \\
\text { mencret (diare) }\end{array}$ \\
\hline 2. & Abu & $\begin{array}{l}\text { Sonneratia } \\
\text { alba } \mathrm{J} . \mathrm{Sm}\end{array}$ & Kulit & $\begin{array}{l}\text { Ambil kulit bagian batang, kemudian kulit } \\
\text { tersebut dikikis dan dimasukan dalam air } \\
\text { panas. Tunggu air tersebut hangat dan } \\
\text { dibuat untuk berkumur }\end{array}$ & Obat sakit gigi \\
\hline
\end{tabular}

Tabel 3. Jenis vegetasi mangrove yang dimanfaatkan sebagai obat oleh suku Inanwatan Sorong Selatan.

\begin{tabular}{|c|c|c|c|c|c|}
\hline No. & $\begin{array}{l}\text { Nama } \\
\text { Lokal }\end{array}$ & $\begin{array}{l}\text { Nama } \\
\text { Latin }\end{array}$ & $\begin{array}{c}\text { Bagian yang } \\
\text { dimanfaatkan }\end{array}$ & Cara Pemanfaatan & Kegunaan \\
\hline 1. & 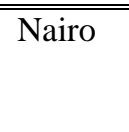 & $\begin{array}{l}\text { Heritera } \\
\text { littoralis }\end{array}$ & $\begin{array}{l}\text { Buah yang } \\
\text { berdiameter 5-6 } \\
\mathrm{cm}\end{array}$ & $\begin{array}{l}\text { Buah mangrove sebanyak } 5-10 \text { buah } \\
\text { dibersihkan, direbus selama } 10 \text { menit lalu } \\
\text { disaring. Air hasil saringan diminum }\end{array}$ & $\begin{array}{l}\text { Untuk } \\
\text { menambah } \\
\text { kekuatan }\end{array}$ \\
\hline
\end{tabular}

Sumber: Bandi (2006)

Tabel 4. Jenis vegetasi mangrove yang dimanfaatkan sebagai obat tradisional oleh suku Mumbay.

\begin{tabular}{|c|c|c|c|c|c|}
\hline No. & $\begin{array}{l}\text { Nama } \\
\text { Lokal }\end{array}$ & Nama Latin & $\begin{array}{c}\text { Bagian yang } \\
\text { dimanfaatkan }\end{array}$ & Cara Pemanfaatan & Kegunaan \\
\hline 1. & Awung & $\begin{array}{l}\text { Soneratia } \\
\text { alba J. Sm }\end{array}$ & Daun & $\begin{array}{l}\text { 5-10 lembar daun muda direbus dengan air } \\
\text { secukupnya lalu diminum }\end{array}$ & $\begin{array}{l}\text { Mempercepat } \\
\text { melahirkan }\end{array}$ \\
\hline 2. & Kabahu & $\begin{array}{l}\text { Xylocarpus } \\
\text { moluccensis }\end{array}$ & Kulit & $\begin{array}{l}\text { Kupas kulit sebanyak satu genggam, } \\
\text { dimasukkan ke timba/ ember, tunggu } 1-2 \text { jam } \\
\text { kemudian air rendaman tersebut dipakai } \\
\text { mandi. }\end{array}$ & $\begin{array}{l}\text { Obat penyakit } \\
\text { kudis }\end{array}$ \\
\hline 3. & Farai & $\begin{array}{l}\text { Rhizopora } \\
\text { apiculata }\end{array}$ & $\begin{array}{l}\text { Batang dan } \\
\text { ranting }\end{array}$ & $\begin{array}{l}\text { Arangnya untuk menghangati bayi agar } \\
\text { tulangnya kuat dan juga untuk menghangati } \\
\text { ibu hamil }\end{array}$ & $\begin{array}{l}\text { Menguatkan } \\
\text { tulang dan } \\
\text { penghangat ibu } \\
\text { hamil }\end{array}$ \\
\hline
\end{tabular}

Tabel 5. Jenis mangrove yang dimanfaatkan sebagai obat tradisional oleh suku Mandori

\begin{tabular}{cccccc}
\hline \hline No. & $\begin{array}{r}\text { Nama } \\
\text { Lokal }\end{array}$ & $\begin{array}{c}\text { Nama } \\
\text { Latin }\end{array}$ & $\begin{array}{c}\text { Bagian yang } \\
\text { dimanfaatkan }\end{array}$ & Cara Pemanfaatan & Kegunaan \\
\hline \hline 1. & Ansius & $\begin{array}{l}\text { Rhizopora } \\
\text { apiculata }\end{array}$ & Kulit & Kulit batang dikupas dan kunyah & $\begin{array}{l}\text { Untuk obat } \\
\text { mencret (diare) }\end{array}$ \\
2. Parem & $\begin{array}{l}\text { Lumnitzera } \\
\text { littorea }\end{array}$ & Bunga & $\begin{array}{l}\text { Ambil bunga segenggam orang dewasa, direbus } \\
\text { sampai mendidih, kemudian didinginkan sampai } \\
\text { hangat-hangat kuku, setelah siap dipakai untuk } \\
\text { mandi bagi orang yang terkena penyakit gatal. }\end{array}$ & Obat gatal \\
\hline \hline Sumber: Krey (2012) & & & &
\end{tabular}

Sumber: Krey (2012) 
Tabel 6. Penyiapan ramuan, cara pemakaian dan jenis penyakit yang diobati pada lima suku pesisir di tanah

\begin{tabular}{|c|c|c|c|}
\hline No & Jenis Penyakit/ Gejala & $\begin{array}{c}\text { Penyiapan Ramuan } \\
\end{array}$ & $\begin{array}{c}\text { Pemakaian } \\
\end{array}$ \\
\hline 1 & Kudis & Bahan direbus dengan air mendidih & $\begin{array}{l}\text { Air rebusan dipakai untuk } \\
\text { mandi }\end{array}$ \\
\hline 2 & Membersihkan kandungan & Bahan direbus dengan air mendidih & Air rebusan diminum \\
\hline 3 & Merangsang balita bicara & Bahan dikunyah & $\begin{array}{l}\text { Kunyahan dioleskan dalam } \\
\text { lidah balita }\end{array}$ \\
\hline 4 & Pengusir nyamuk & Buah dikeringkan & Dibakar \\
\hline 5 & Pestisida alami & Buah dihancurkan & Dihambur di sekitar tanaman \\
\hline 6 & Sakit gigi & Bahan direbus & Berkumur dengan air rebusan \\
\hline 7 & Malaria & Direndam & Air rendaman diminum \\
\hline 8 & Diare & Kulit dibersihkan & Dikunyah \\
\hline 9 & Stimulan energi & Bahan direbus & Air rebusan dimimun \\
\hline 10 & $\begin{array}{l}\text { Perangsang/ } \\
\text { Mempercepat melahirkan }\end{array}$ & Bahan direbus & Air rebusan diminum \\
\hline 11 & Menguatkan tulang & Bahan dibakar menjadi arang & Pemijatan \\
\hline 12 & Obat gatal & Bahan direbus & Air rebusan untuk mandi \\
\hline
\end{tabular}

\section{Simpulan dan Saran}

\section{Simpulan}

Tujuh jenis dari lima famili vegetasi mangrove dimanfaatkan oleh lima suku di pesisir pantai tanah Papua obat tradisional untuk berbagai gejala penyakit seperti, kudis, malaria, gatal-gatal, sakit gigi, obat nyamuk, pestisida alami, dan menambah stamina (stimulan). Vegetasi mangrove tersebut juga dimanfaatkan sebagai obat untuk membersihkan kandungan, merangsang balita untuk cepat dan pintar berbicara, penguat tubuh dan perangsang ibu melahirkan. Bagian tumbuhan yang dimanfaatkan beragam, dari akar, kulit, daun, dan buah. Pengetahuan tradisional pemanfaatan vegetasi mangrove sebagai obat tradisional diperoleh dari pengetahuan turun-temurun dan uji coba. Terdapat sedikit perbedaan pemanfaatan vegetasi mangrove antara sukusuku pesisir di tanah Papua.

\section{Saran}

Perlu dilakukan penelitian yang sama pada suku-suku di Papua yang berdomisili di sekitar mangrove, mengingat jumlah suku yang ada di Papua lebih dari 250 suku. Setiap vegetasi mangrove yang dimanfaatkan sebagai obat tradisional, perlu diteliti kandungan kimia, bahan aktif atau senyawa bahan kimia yang terkandungnya.

\section{Ucapan Terima Kasih}

Terima kasih kepada semua pihak yang berpartisipasi dalam penelitian ini, terutama kepada Direktorat Jenderal Pendidikan Tinggi.

\section{Daftar Pustaka}

Abidondifu, Y.D. 2007. Pengetahuan Lokal Pemanfaatan Vegetasi Mangrove oleh Suku Mandender di Kampung Duai Kabupaten Biak Numfor. Skripsi Sarjana Kehutanan UNIPA Manokwari.

Baba, S., Chan, H.T. dan Aksornkoae, S. 2013. Useful Products from Mangrove and other Coastal Plants. ISME Mangrove Educational Book Series No. 3. International Society for Mangrove Ecosystems (ISME), Okinawa, Japan, and International Tropical Timber Organization (ITTO), Yokohama, Japan.

Bandaranayake, W.M. 2002. Bioactivities, bioactive compounds, and chemical constituents of mangrove plants. Wetlands Ecology and Management, 10: 421-452.

Bandaranayake, W.M. 1998. Traditional and Medicinal Uses of Mangroves. Mangrove and Salt Marshes, 2: 133-148.

Bandi, H.L. 2006. Pemanfaatan Vegetasi Mangrove oleh Masyarakat suku Inanwatan di Kampung Sibay Distrik Inanwatan Sorang Selatan. Skripsi Sarjana Kehutanan Fahutan UNIPA Manokwari.

Kasi, N. 2009. Pemanfaatan Tumbuhan sebagai Bahan obat oleh suku Meyakh di Kampung Saray Distrik Sidey Kabupaten Manokwari. Skripsi sarjana Kehutanan Fahutan Unipa. Manokwari. 
Krey, E. 2012. Pemanfaatan Tumbuhan Mangrove oleh Masyarakat Suku Mandori Distrik Bruyadori Kabupaten Biak Numfor. Skripsi Sarjana Kehutanan UNIPA Manokwari.

Laksono, P. M., Sumijati, A.S., Gandarsih, T., Pakpahan, M. dan Rianty, A. 2000. Perempuan di Hutan Mangrove. Kearifan Ekologis Masyarakat Papua. Pusat Studi Asia Pasifik Universitas Gaja Mada Bekerjasama dengan Galang Press Yogyakata dan Yayasan KEHATI Jakarta.

Leonard. 2003. Pemanfaaatan Vegetasi Mangrove Oleh masyarakat Suku Senebuay. Skripsi Sarjana Kehutanan fahutan Unipa. Manokwari.

Mahmud. 2011. Vegetasi Mangrove Sebagai Makanan pada empat suku di Papua. Biota, 16 (1): 88-94.

Purnobasuki, H. 2004. Potensi Mangrove sebagai Tanaman Obat. Biota, 9 (2) : 125-126.

Rumadas, Y.K. 2012. Etnobotani Masyarakat Adat Byak di Kampung Swaipak Distrik Swandive Kab. Biak Numfor. Skripsi Sarjana Kehutanan Fahutan Univ. Negeri Papua. Manokwari.
Santoso, N., Nurchaya, B.C., Siregar, A.F. dan Farida, I. 2005. Resep Makanan Berbahan Baku Mangrove dan Pemanfaatan Nipah. Lembaga Pengkajian dan Pengembangan Mangrove. Jakarta.

Sihite, J., Lense, O., Surartri, R., Gustiar, C. dan Kosamah, S. 2005. Cagar Alam, Mutiara Hijau Teluk Bintuni. The Nature Conservansy (TNC), Southeast Asia Center for Marine. Protected Areas (SEA CMPA). Kerjasama Lembaga Penelitian Universitas Trisakti, Jakarta Barat.

Wahyudi. 2012. Advanced Utilization of Tali Kuning (Tinospora dissitifroraDiles). Dissertation. United Graduated of Agricultural Sciences, Ehime University, Matsuyama, Japan.

Wibowo, C., Kusmana, C., Suryani, A., Hartati, Y. dan Oktadiyani, P. 2009. Pemanfaatan Pohon Mangrove Api-api (Avicennia spp) sebagai bahan pangan dan obat. Proseding seminar hasil-hasil penelitian IPB: 158-166. 